УДК 330.322:330.341

Глівінська Ю. В. gyv0503@gmail.com,ORCID ID:0000-0003-2957-0296

к.е.н., дочент кафедри міжнародних відносин та туризму, Київський міжнародний університет, м. Київ

\title{
СИСТЕМНА СУТНІСТЬ КАТЕГОРІАЛЬНИХ ПОНЯТЬ МЕХАНІЗМІВ ІННОВАЦІЙНО-ІНВЕСТИЦИЙНОГО ПОТЕНЦІАЛУ ЕКОНОМІЧНОГО РОЗВИТКУ
}

\begin{abstract}
Анотація. У статті розглянуто трактування сутності терміна «потенціал» як складного, багатоманітного поняття, щчо поєднує насамперед ресурси, засоби, джерела, необхідні для функціонування системи, котрі в разі реалізачії можливості їх мобілізащії $і$ використання за певних умов здатні надати розвитку системи якісно нового імпульсу. Загальновідомо, щзо стрімкий економічний і науковотехнологічний розвиток розвинених економік у другій половині XX cm. пов'язаний зі значною кількістю винаходів та нововведень. Поява інновацій, які суттєво вплинули на продуктивність праці та витрати виробництва, стала результатом дії науково-технічного прогресу. Відповідно, трансфер технологій, імплементація нововведень у виробництво потребують великих фінансових ресурсів, інвестицій, щзо й зумовлює поєднання категорій «інноващії» та «інвестиції». Розкрито сутність інноваційного та інвестиційного потенціалів та описано їхні складники. Удосконалено трактування поняття інноваційно-інвестиційного потенціалу економічного розвитку на засадах сталості як здатність економічної системи за збалансованими екологічним та сочіальним складниками розвитку до здійснення інноваційної діяльності за наявності сприятливого інвестиційного середовищуа. Реалізація інноваційно-інвестиційного потенціілу неможлива без механізмів його формування та використання, тому, узагальнюючи підходи до трактування сутності понять «господарський механізм», «економічний механізм», «інституційний механізм», було запропоновано парадигму: механізму формування інноваційно-інвестиичійного потенціалу, який визначено як систему причино-наслідкових та обернених зв'язків між усіма елементами потенціалу в усіх сферах національної економіки та різних рівнях господарювання для підвищення ефективності його застосування; механізму використання інноваційно-інвестиційного потенціалу, в основі якого лежить узгодження приватних і суспільних інтересів на основі вдосконалення нормативно-правового забезпечення, зміни економічної структури національного господарства, здійснення моніторингу діяльності суб'єктів економіки, інформачійно-аналітичного та кадрового забезпечення процесу залучення інвестиційних ресурсів, щзо знаходить вираз у изілях, формах і результатах їх взаємодї на всіх рівнях.
\end{abstract}

Ключові слова: інноваційно-інвестиційний потенціал, механізми, економічний розвиток, ресурси, інноваційна культура.

\section{Hlivinska Yuliia}

gyv0503@gmail.com,ORCID ID: 0000-0003-2957-0296

Ph.D., Associate Professor at the Department of International Relations and Tourism, Kyiv International University, Kyiv

\section{SYSTEMIC ESSENCE OF CATEGORIAL CONCEPTS OF MECHANISMS OF INNOVATION AND INVESTMENT POTENTIAL OF ECONOMIC DEVELOPMENT}

\footnotetext{
Abstract. The article considers the interpretation of the essence of the concept of potential as a complex, diverse concept that combines resources, tools, sources necessary for the functioning of the system, which in case of realization of their mobilization and use under certain conditions can give the system a qualitatively new impetus. It is well known that the rapid economic and scientific and technological development of developed economies in the second half of the twentieth century associated with a significant number of inventions and innovations. The emergence of innovations that have significantly affected labor productivity and production costs has been the result of scientific and technological progress. Accordingly,
} 
technology transfer and implementation of innovations in production require large financial resources and investments, which determines the combination of categories of innovation and investment. The essence of innovation and investment potentials is revealed and their components are described. The interpretation of the concept of innovation and investment potential of economic development on the basis of sustainability as the ability of the economic system for a balanced environmental and social components of development to carry out innovative activities in the presence of a favorable investment environment. Realization of innovation and investment potential is impossible without mechanisms of its formation and use, therefore generalizing approaches to interpretation of essence of concepts "economic mechanism", "economic mechanism", "institutional mechanism", the paradigm was offered: the mechanism of formation of innovation and investment potential which is defined as system causal and inverse relationships between all elements of capacity in all areas of the national economy and different levels of management to increase the efficiency of its application; mechanism for using innovation and investment potential, which is based on the coordination of private and public interests through the improvement of regulatory and legal support, changes in the economic structure of the national economy, monitoring the activities of economic entities, information-analytical and staffing of investment resources, which is expressed in goals, forms and the results of their interaction at all levels.

Key words: innovation and investment potential, mechanisms, economic development, resources, innovation culture.

\section{JEL Classification: O10, O15, M14 \\ DOI: https://doi.org/10.36477/2522-1256-2021-30-03}

Постановка проблеми. Передумовою довготривалого економічного зростання України є наукові надбання та їх технологічне застосування, що створюють можливість підвищувати конкурентоспроможність економіки, гарантувати економічну безпеку та впливають на інтеграцію держави у високотехнологічне конкурентне середовище. В умовах глобалізації та посилення світової конкуренції актуальність досліджень у сфері інноваційно-інвестиційної діяльності набуває особливого значення. Світовий досвід доводить, що інтенсивність інноваційно-інвестиційної діяльності суттєво впливає на рівень економічного розвитку. Економічне зростання країни повинно забезпечуватися провідною роллю науково-технічного прогресу та інтелектуалізацією основних складників виробництва в усіх сферах економіки [8].

Аналіз останніх досліджень і публікацій. Результати досліджень теоретичних і практичних проблем сутності інноваційного та інвестиційного потенціалів ринкової економіки, розвитку національної інноваційної системи висвітлено в роботах таких вітчизняних та зарубіжних дослідників, як: О. Алимов, О. Амоша, В. Базилевич, Л. Беззубко, С. Бельтюков, Л. Борщ, В. Бочарова, 3. Варналій, В. Геєць, Н. Гражевська, Н. Дучинська, П. Єщенко, А. Жетписпаєв, Е. Забарна, В. Зянька, Р. Кармов, В. Кириленко, К. Клімова, М. Ковальов, К. Ковтуненко, Д. Кокурін, О. Кузьмін, В. Лисюк, І. Лицур, М. Меркулов, В. Микитенко, П. Нікітенко, М. Нікіфорова, С. Онишко, А. Пересада, А. Алчіан, П. Кругман, М. Портер, С. Соете, Дж. Стігліц, К. Фрімен, У. Шарп. В окремих дослідженнях інноваційно-інвестиційна система розглядається лише як кінцева мета відпо- відної національної політики, а не як її ключовий інструмент.

Значимість цих питань у контексті глобальної модернізації потребує проведення подальших досліджень у галузі теоретичного визначення сутності інноваційно-інвестиційного потенціалу економічного розвитку, механізмів його формування та використання.

Постановка завдання. Метою роботи є визначення сутності категоріальних понять механізмів інноваційно-інвестиційного потенціалу економічного розвитку.

Виклад основного матеріалу дослідження. В Україні одним із негативних наслідків перехідного періоду в економіці стало різке зниження показників інноваційної діяльності у виробництві. Це означає, що інноваційні кошти здебільшого витрачалися не на фінансування розвитку вітчизняної науки, а на зміцнення іноземних компаній шляхом придбання готової наукоємної продукції. I тому важливими $\epsilon$ правильний вибір стратегії розвитку інноваційно-інвестиційної сфери, що спрямований на подолання технологічного відставання національної економіки, та перехід на інноваційний шлях розвитку [8].

Питання переходу України до інноваційної моделі розвитку привертає до себе дедалі більшу увагу науковців, політиків, практиків бізнесу. Цілком слушними $є$ їхні погляди, що створення належних стимулів для поширення інноваційної моделі економічної поведінки українського бізнесу стало пріоритетним завданням політики держави.

Поділяючи їхні погляди, зазначимо, що інноваційна діяльність підприємств сьогодні є об'єктом 
поєднання інтелектуальних, фінансових, матеріальних та інших процесів укладання ресурсів iз метою, насамперед, отримання економічного ефекту. Розв'язання проблем активізації інноваційної діяльності підприємств можливе за умови наукового обгрунтування й спроможності суб'єктів господарювання до неї, наявності у них передусім необхідного інноваційного потенціалу.

Трактування змісту поняття «потенціал» дають змогу зрозуміти його природу та основну сутність. Остання розкривається через три взаємопов'язані та взаємозалежні ознаки: його зміст - засоби, запаси, ресурси; здатність, можливість та необхідність мобілізації цих ресурсів, засобів; мету мобілізації і використання зазначених ресурсів. Отже, реалізація потенціалу загалом, як й інноваційноінвестиційного зокрема, потребує наявності всіх трьох його складників, іманентно притаманних умов. По-різному трактують поняття «потенціал» вітчизняні та іноземні вчені (табл. 1).

Отже, виходячи 3 наведених тлумачень, термін «потенціал» можна охарактеризувати як складне, багатоманітне поняття, що поєднує насамперед ресурси, засоби, джерела, необхідні для функціонування системи, котрі в разі реалізації можливості їх мобілізації і використання за певних умов здатні надати розвитку системи якісно нового імпульсу.

Загальновідомо, що стрімкий економічний $\mathrm{i}$ науково-технологічний розвиток розвинених економік у другій половині ХX ст. пов'язаний зі значною кількістю винаходів та нововведень. Поява інновацій, які суттєво вплинули на продуктивність праці та витрати виробництва, стала результатом дії науково-технічного прогресу. Відповідно, трансфер технологій, імплементація нововведень у виробництво потребують великих фінансових ресурсів, інвестицій, що й зумовлює поєднання категорій «інновації» та «інвестиції» [8].

Категорія «інноваційно-інвестиційний потенціал» (ІІП) стала об'єктом дослідження зарубіжних науковців у середині $70-\mathrm{x}$ років XX ст. Най- частіше вони розкривають сутність ІІП шляхом аналізу його структури, виділяючи дві його взаємодоповнюючі підсистеми - інноваційний та інвестиційний потенціали.

Варто зазначити, що інноваційна система загалом та інноваційний потенціал зокрема $є$ основою, ресурсною базою інтенсивного економічного розвитку держави [8].

3 огляду на основну ознаку сутності інноваційного потенціалу як чинника економічного розвитку, можна виділити чотири підходи до його тлумачення (табл. 2).

Таким чином, інноваційний потенціал можна охарактеризувати як складову частину економічного потенціалу, яка містить систему ресурсів, здібностей та можливостей, котрі забезпечують спроможність і здатність здійснювати інноваційну діяльність, упровадження досягнень НТП, розроблення та реалізацію нововведень та підтримку інноваційного процесу, перехід у якісно новий стан розвитку з метою досягнення конкурентоспроможності економіки.

Загальновідомо, що сутність будь-якого предмета чи об'єкта пізнається через його структуру. Щодо інноваційного потенціалу, то найчастіше науковці виділяють три основні його складники: ресурсний, результативний та внутрішній. Слід зазначити, що таке структурування, запропоноване Д. Кокуріним [6, с. 126], було доповнене вітчизняним дослідником Л. Беззубком, який додатково виокремив четвертий складник інноваційного потенціалу - інноваційну культуру (рис. 1).

Ресурсний складник інноваційного потенціалу є іiі основним фундаментальним елементом та безпосередньо впливає на формування інноваційного потенціалу. Він містить у собі компоненти, що мають різне функціональне призначення: фінансові, матеріально-технічні, інформаційні, людські та інші види ресурсів.

Важливим елементом інноваційного потенціалу $\epsilon$ його результативний складник, що виражає мету використання інноваційного потенціалу-створення

Таблиця 1

Трактування сутності поняття «потенціал» різними науковцями

\begin{tabular}{|l|l|}
\hline \multicolumn{1}{|c|}{ Дослідник } & \multicolumn{1}{|c|}{ Трактування } \\
\hline Г. Нойбауер & $\begin{array}{l}\text { Засоби, запаси, джерела, що можуть бути використанні для вирішення певного } \\
\text { завдання, досягнення визначеної мети, можливості суспільства, держави в певній } \\
\text { сфері [14, с. 65] }\end{array}$ \\
\hline Д. Черников & $\begin{array}{l}\text { Сукупність необхідних для функціонування або розвитку системи різних видів } \\
\text { ресурсів }\end{array}$ \\
\hline Л. Абалкін & Узагальнена збірна характеристика ресурсів, прив’язана до місця і часу \\
\hline Б. Мочалов & $\begin{array}{l}\text { Сукупність накопичених ресурсів, їхніх використаних і невикористаних потенційних } \\
\text { можливостей у сфері виробництва матеріальних благ та послуг із метою найбільш } \\
\text { повного задоволення потреб суспільства }\end{array}$ \\
\hline В. Архангельський & $\begin{array}{l}\text { Засоби, запаси, джерела, які є в наявності і можуть бути мобілізовані для досягнення } \\
\text { певної мети або розв’язання певного завдання }\end{array}$ \\
\hline
\end{tabular}

Джерело: розроблено автором 
Таблиця 2

Трактування поняття «інноваційний потенціал» зарубіжними та вітчизняними дослідниками

\begin{tabular}{|c|c|c|}
\hline Підхід, зріз & Дослідник & Трактування \\
\hline $\begin{array}{l}\text { 1. Складник } \\
\text { інтелектуального } \\
\text { потенціалу }\end{array}$ & $\begin{array}{l}\text { С. Лапин } \\
{[7, \text { с. } 37-38]}\end{array}$ & $\begin{array}{l}\text { Разом з інформаційним потенціалом є складовими } \\
\text { частинами інтелектуального потенціалу підприємства, } \\
\text { котрі допомагають підвищити рівень і ефективність } \\
\text { технологій }\end{array}$ \\
\hline $\begin{array}{l}\text { 2. Інтегральна сукупність } \\
\text { потенціалів і складник } \\
\text { економічного потенціалу }\end{array}$ & Н. Папп $[15$, с. 98$]$ & $\begin{array}{l}\text { Сдність і взаємодія наукового, освітнього, } \\
\text { управлінського і модернізованої частки освітнього } \\
\text { потенціалу }\end{array}$ \\
\hline \multirow{2}{*}{$\begin{array}{l}\text { 3. Здатність системи } \\
\text { до зміни досягнення } \\
\text { нового стану }\end{array}$} & $\begin{array}{l}\text { Е. Марченко, } \\
\text { М. Разумова [10] }\end{array}$ & $\begin{array}{l}\text { Здатність, можливість системи до трансформації } \\
\text { фактичного порядку речей у новий стан із метою } \\
\text { задоволення існуючих або нових виникаючих потреб }\end{array}$ \\
\hline & $\begin{array}{l}\text { Л. Беззубко } \\
{[2, \text { с. } 11]}\end{array}$ & $\begin{array}{l}\text { Характеристика здатності системи до зміни, } \\
\text { удосконалення, прогресу }\end{array}$ \\
\hline $\begin{array}{l}\text { 4. Сукупність ресурсів, } \\
\text { що забезпечують } \\
\text { здійснення інноваційної } \\
\text { діяльності }\end{array}$ & $\begin{array}{l}\text { І. Балабанов } \\
{[1, \text { с. } 201]}\end{array}$ & $\begin{array}{l}\text { Сукупність різних видів ресурсів, включаючи } \\
\text { матеріальні, фінансові, інтелектуальні, науково- } \\
\text { технічні, необхідні для здійснення інноваційної } \\
\text { діяльності }\end{array}$ \\
\hline
\end{tabular}

Джерело: систематизовано автором

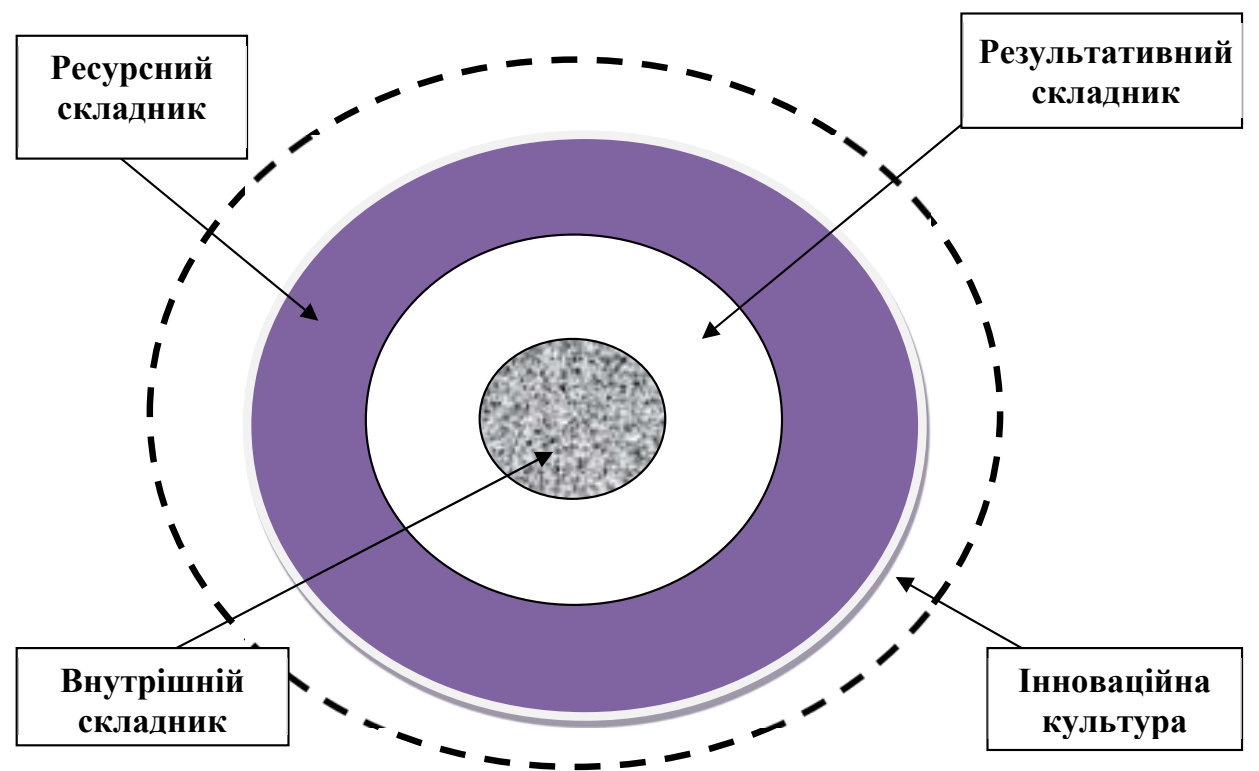

Рис. 1. Структура інноваційного потенціалу [2, с. 13]

або поліпшення товару, удосконалення технології виробничого процесу. Фактично цей компонент визначає можливості відтворення, нагромадження і збільшення інших складників потенціалу, особливо ресурсного. Водночас ефективне поєднання i використання ресурсної компоненти створює передумови для реалізації результативного складника. Саме у цьому й полягає діалектика взаємозв'язку елементів інноваційного потенціалу.

Внутрішній складник інноваційного потенціалу є не що інше, як механізм, що забезпечує поєднання і використання ресурсної та результативної компонент. Він характеризує цілеспрямованість інноваційної діяльності, можливість досягнення поставлених цілей та виконання завдань, включає способи і методи управління інноваційним процесом. Іншими словами, цей складник відповідає за всі етапи реалізації останнього, включаючи створення і генерацію нового продукту, його вдосконалення, забезпечуючи зв'язок виробництва 3 наукою через трансфер технологій і виробництва 3 ринком, реалізуючи ідеї, вимоги та запити споживчого попиту [8].

Інноваційна культура як компонент інноваційного потенціалу являє собою ступінь сприйнятливості організації (регіону, країни) до нововведень, досвід упровадження нових проєктів, політик менеджменту у сфері інновацій, відношення персоналу (людей) до новацій [2, с. 17]. Цей складник $\epsilon$ каталізатором відтворення інновацій. 
Іншою підсистемою ІІП $є$ його інвестиційний потенціал, що органічно співіснує 3 інноваційним, взаємодоповнюючи один одного. Діалектика їх взаємодії полягає у тому, що реалізація інвестиційного потенціалу здатна забезпечити перехід від економічного зростання до інтенсивного економічного розвитку лише за умови залучення та використання інноваційного потенціалу. Своєю чергою, інноваційний процес, генерування новацій, трансфер інновацій економічно обгрунтовані та можливі лише за наявності інвестиційних ресурсів.

На основі узагальнення наявних підходів виділено п'ять основних трактувань інвестиційного потенціалу (табл. 3).

Сучасне трактування інвестиційного потенціалу відображає четвертий підхід [17, с. 58].

Заслуговує на увагу позиція російського дослідника В. Бочарова, згідно 3 якою інвестиційна діяльність відбувається в ринкових умовах, де на інвестиційному ринку взаємодіють такі його елементи, як інвестиційний попит і пропозиція [3].

Таким чином, інвестиційний потенціал економіки - це система фінансових, трудових, технічних ресурсів, що забезпечують інвестиційну привабливість економіки, відображають здатність до інвестування та до абсорбції капіталу з метою задоволення потреб розширеного відтворення.

Інвестиційний потенціал органічно співіснуе 3 інноваційним потенціалом, взаємодоповнюючи один одного. Діалектика взаємодії інноваційного та інвестиційного потенціалу полягає у тому, що реалізація інвестиційного потенціалу здатна забезпечити перехід від економічного зростання до інтенсивного економічного розвитку лише за умови залучення та використання інноваційного потенціалу. Своєю чергою, інноваційний процес, генерування новацій та трансфер інновацій економічно обгрунтовані та можливі лише за наявності інвестиційних ресурсів [8].

Результати аналізу виявили, що дослідженню IIП на макрорівні приділяється недостатньо уваги з боку дослідників. Вітчизняний науковець Н. Мешко розглядає інвестиційно-інноваційний потенціал держави як сукупність потенціалів регіонів, посилену ефектом синергії й організаційним механізмом цілеспрямованої державної політики на сталий економічний розвиток та зміцнення міжнародного становища держави [8].

Водночас вітчизняний економіст Е. Забарна трактує ІІП як здатність господарської одиниці розвиватися на власній основі в майбутньому, що підкріплена сукупністю наявних ліквідних ресурсів і можливостей економіки їх використовувати на фінансування інвестицій із метою динамічного розвитку та підвищення конкурентоспроможності [5, c. 117$]$.

Інноваційно-інвестиційний потенціал економічного розвитку містить два складники: інноваційний та інвестиційний, що представлено на рис. 2.

Інноваційний потенціал виражається через здатність до: акумулювання фінансових і матеріальних ресурсів для здійснення інноваційної діяльності; формування та реалізації інноваційних програм; ефективне використання та зростання інтелектуального капіталу.

Під інвестиційним складником пропонується розуміти здатність задіяти інвестиційний потенціал із метою підвищення інвестиційної привабливості та інвестиційної активності галузей, що створює потенційні можливості фінансового забезпечення інноваційних процесів, здійснювати фінансові та або реальні інвестиції.

Таблиця 3

Трактування категорії «інвестиційний потенціал» іноземними та вітчизняними науковцями

\begin{tabular}{|l|l|l|}
\hline \multicolumn{1}{|c|}{ Підхід до визначення } & \multicolumn{1}{|c|}{ Дослідник } & \multicolumn{1}{|c|}{ Трактування } \\
\hline 1. Ресурси інвестицій & А. Алчіан [18, с. 80] & $\begin{array}{l}\text { Упорядкована маса фінансових, технічних } \\
\text { i трудових ресурсів, які спрямовуються в економіку } \\
\text { i забезпечують розширення їі можливостей } \\
\text { вирішувати проблеми соціального розвитку }\end{array}$ \\
\hline $\begin{array}{l}\text { 2. Можливість взаємодії } \\
\text { інвестора та реципієнта }\end{array}$ & $\begin{array}{l}\text { В. Соболєв, } \\
\text { В. Шердяков } \\
\text { [17, с. 58] }\end{array}$ & $\begin{array}{l}\text { Діалектика взаємодії інвесторів та реципієнтів } \\
\text { інвестицій стосовно використання джерел } \\
\text { довгострокового прогресивного розвитку в окремому } \\
\text { господарському середовищі }\end{array}$ \\
\hline $\begin{array}{l}\text { 3. Інвестиційна } \\
\text { привабливість }\end{array}$ & $\begin{array}{l}\text { Сума окремих потенціалів, що характеризують } \\
\text { основні макроекономічні параметри регіону } \\
\text { і впливають на його інвестиційну привабливість }\end{array}$ \\
\hline $\begin{array}{l}\text { 4. Ресурсне забезпечення } \\
\text { розширеного відтворення }\end{array}$ & Н. Намлієва [13] & $\begin{array}{l}\text { Можливості підприємства задовольняти потреби } \\
\text { розширеного відтворення }\end{array}$ \\
\hline $\begin{array}{l}\text { 5. Взаємодія інвестиційного } \\
\text { попиту та пропозиції }\end{array}$ & В. Бочаров [3] & $\begin{array}{l}\text { Реальна пропозиція інвестиційних ресурсів (капіталу), } \\
\text { опосередкована конкретним (або потенційним } \\
\text { попитом) }\end{array}$ \\
\hline
\end{tabular}

Джерело: систематизовано автором 


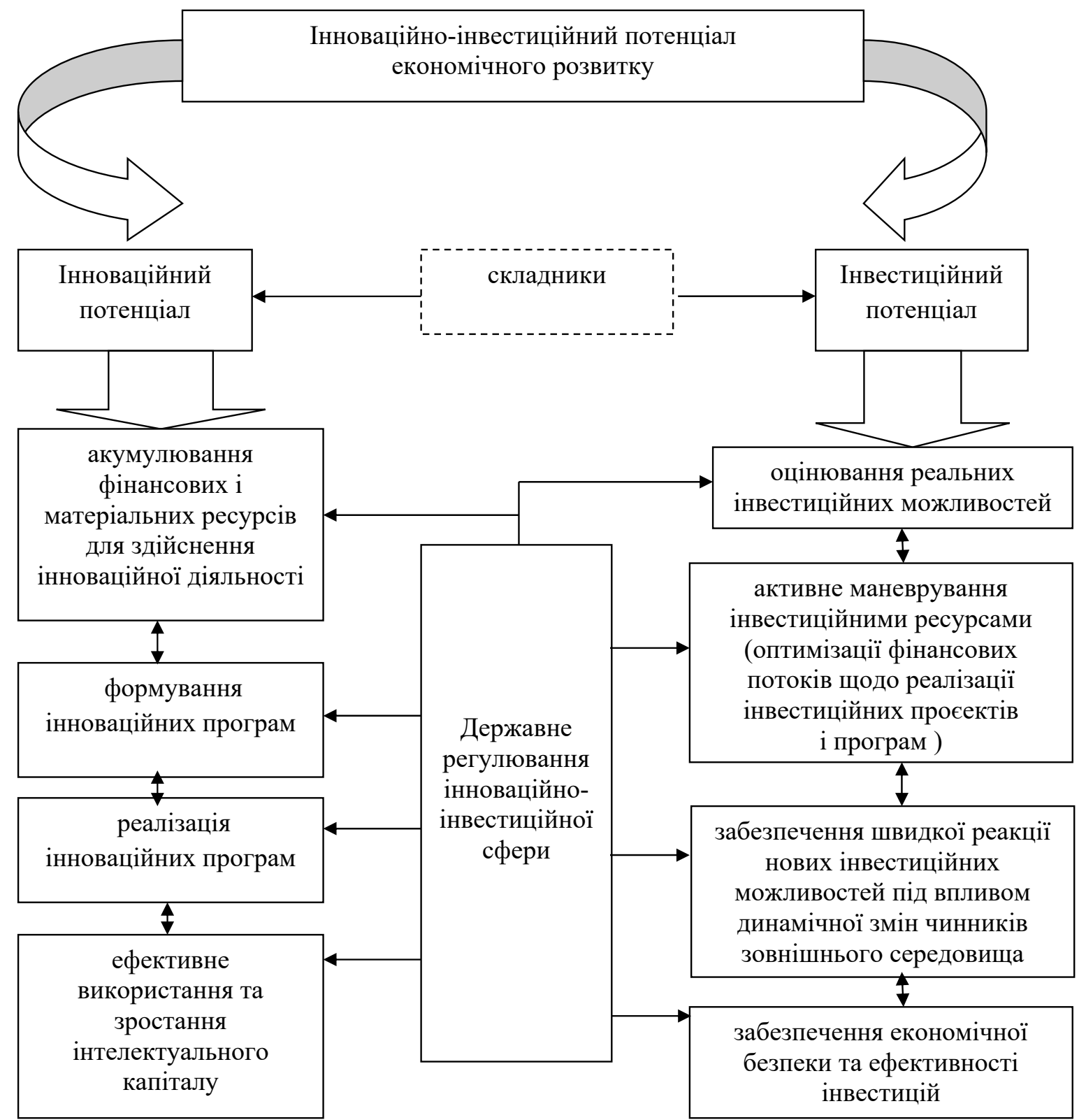

Рис. 2. Схема складників інноваційно-інвестиційного потенціалу економічного розвитку

Джерело: розроблено автором

Інвестиційний складник інноваційно-інвестиційного потенціалу характеризує здатність до: оцінювання реальних інвестиційних можливостей галузей; активного маневрування інвестиційними ресурсами (оптимізації фінансових потоків щодо реалізації інвестиційних проєктів і програм); забезпечення швидкої реакції нових інвестиційних можливостей під впливом динамічних змін чинників зовнішнього середовища; забезпечення економічної безпеки та ефективності інвестицій.

На основі зазначеного вище поняття інноваційно-інвестиційного потенціалу економічного розвитку на засадах сталості дефініційно визначено як здатність економічної системи за збалансованими екологічним та соціальним складниками розвитку до здійснення інноваційної діяльності за наявності сприятливого інвестиційного середовищиа [8].

Варто відзначити, що реалізація інноваційно-інвестиційного потенціалу неможлива без механізмів його формування та використання. Це, своєю чергою, вимагає розуміння сутності механізму.

Отже, термін «механізм» (3 грец. mechane машина) означає пристрій, що передає або перетворює рух; внутрішню будову, систему чого-небудь; сукупність станів і процесів, з яких складається певне явище [4, с. 523].

Поняття «механізм» використовується представниками різних наук, тому існує велика кіль- 
кість підходів до визначення сутності даного поняття. Сучасні науковці розглядають термін «механізм» у різноманітних площинах: як «господарський механізм», «економічний механізм», «інституційний механізм», «механізм управління», «фінансовий механізм» тощо.

Аналіз літературних джерел щодо дослідження змісту поняття «механізм» із погляду зв'язків між явищами і процесами дав змогу виділити низку підходів до його трактування. Розглянемо підходи до сутності понять «господарський механізм», «економічний механізм» та «інституційний механізм».

С. Мочерний указує, що формування господарського механізму являе собою систему основних форм, методів і важелів використання економічних законів, розв'язання протиріч суспільного виробництва, реалізації форм власності, а також усебічного розвитку людини та узгодження його інтересів 3 інтересами колективу, класу, суспільства [12].

I.I. Лукінов категорію економічного механізму визначає як складну сукупність регуляторів, за допомогою яких реалізуються складники загальнодержавної та ринкової політики: монетарної, валютної, цінової, фінансової, банківськокредитної, платіжної, податкової, митної, страхової тощо [9].

Поняття «інституційний механізм» досліджував Д.В. Приймаченко, який визначає дане поняття як сукупність взаємозв'язків між формальними та неформальними інститутами, а також організаціями, які сприяють реалізації принципів демократичного (доброго, належного) врядування, забезпечують узгодження та коригування інтересів різних суспільних груп, координацію сумісної діяльності на шляху досягнення задекларованих цілей розвитку регіону/держави [16].

Узагальнюючи вищенаведені підходи до трактування сутності понять «господарський механізм», «економічний механізм», «інституційний механізм», запропонуємо парадигму механізму формування інноваційно-інвестиційного потенціaлy, який визначено як систему причино-наслідкових та обернених зв'язків між усіма елементами потенціалу в усіх сферах національної економіки та різних рівнях господарювання для підвищення ефективності його застосування; механізму використання інноваційно-інвестиційного потенціалу, в основі якого лежить узгодження приватних i суспільних інтересів на основі вдосконалення нормативно-правового забезпечення, зміни економічної структури національного господарства, здійснення моніторингу діяльності суб'єктів економіки, інформаційно-аналітичного та кадрового забезпечення процесу залучення інвестиційних ресурсів, що знаходить вираз у цілях, формах i результатах їх взаємодії на всіх рівнях [8].
Висновки 3 проведеного дослідження. Необхідність вирішення питань, пов'язаних 3 інноваційно-інвестиційним розвитком економіки України, сьогодні набуває особливого значення i неможлива без здійснення державою рішучих дій у напрямі стимулювання інноваційноінвестиційної діяльності. Державна інноваційноінвестиційна політика має стати найважливішим кроком для переходу України на інноваційний тип економіки. Головною метою такої політики є стратегічна орієнтація розвитку виробництва на створення та широке застосування принципово нової техніки, матеріалів, комплексних технологічних систем, ефективне освоєння науково-технічних розробок, забезпечення соціально-економічних, організаційних і правових умов для постійного здійснення ефективної інноваційної діяльності.

\section{ЛIТЕРАТУРА}

1. Балабанов И. Т. Кратний курс инновационного менеджмента : учебное пособие. Санкт-Петербург, $2000.350 \mathrm{c}$.

2. Беззубко Л. В., Захаров С. С., Свєшнікова Н. М. Інноваційний потенціал. Донецьк, 2008. 202 с.

3. Бочаров В. В. Финансово-кредитные методы регулирования рынка инвестиций. Москва : Финансы и статистика, 1993. 144 с.

4. Великий тлумачний словник сучасної української мови / уклад. і гол. ред. В. Т. Бусел. Київ ; Ірпінь : Перун, 2003. 1440 c.

5. Забарна Е. М. Інноваційно-інвестиційний фактор економічного розвитку України. Одеса : Ін-т проблем ринку та екон.-екол. дослід. НАН України, 2006. $304 \mathrm{c}$.

6. Кокурин Д. И. Инновационная деятельность. Москва : Экзамен. 2001. 575 с.

7. Лапин Е. В. Экономический потенциал предприятия : монографія. Сумы : Унив. книга, 2002. $310 \mathrm{c}$.

8. Лимич Ю. В. Механізми формування та використання інноваційно-інвестиційного потенціалу економічного розвитку : дис. ... канд. ек. Наук : 08.00.03. Одеса, 2015. $210 \mathrm{c.}$

9. Лукінов І. І. Економічні трансформації (наприкінці ХХ сторіччя). Київ : IЕ НАН України, 1997. $456 \mathrm{c}$.

10. Марченко Е. М., Разумова М. В. К вопросу об оценке инновационного потенциала. ВлГУ. 2007. № 18. C. 16.

11. Мешко Н. П. Інвестиційно-інноваційний потенціал регіону: критерії оцінки та проблеми формування. Економічний простір. 2008. № 10. С. 78-88.

12. Мочерный С. В. и др. Экономическая теорія. URL: http://library.tuit.uz/skanir_knigi/book/econ_teo riya/econ_teoriya.htm.

13. Намлієва Н. В. Регламентація системи управління інвестиційним потенціалом підприємств. Материалы Международной Интернет-конференции «Современное состояние и перспективы развития финансового права», 28 октября 2009 г. URL: http://ndi-fp.asta.edu.ua/conf/index.php?topic=47.0. 
14. Нойбауэр Х. Инновационная деятельность на малых и средних предприятиях. Проблемы теории и практики управления. 2002. № 3. С. 65-67.

15. Папп Н. В. Особливості формування інноваційного потенціалу регіону. Наука в інформаційному просторі : матеріали V Міжнар. наук.-практ. конф., 30-31 жовтня 2009 р. : у 6 т. Дніпропетровськ, 2009. С. 68-70.

16. Приймаченко Д. В. Інституціональний механізм формування та реалізації митної політики. Підприємниитво, господарство $i$ право. 2005. № 11. C. $17-20$.

17. Соболєв В. М., Шердяков В. Е. Менеджмент в области инвестиций и персонала: особенности в переходной экономики. Харьков : Бизнес Информ, 1996. $176 \mathrm{c.}$

18. Alchian A. Economic Forces at Work. Indianpolis. 1977. $246 \mathrm{p}$.

\section{REFERENCES}

1. Balabanov, I. T. (2000), "Multiple course of innovation management: textbook. allowance", St. Petersburg, Russia.

2. Bezzubko, L. V., Zakharov, S. E. and Sveshnikova, N. M. (2008), "Innovative potential", Donetsk, Ukraine.

3. Bocharov, V. V. (1993), "Financial and credit methods of investment market regulation", Finance and Statistics, Moscow, Russia.

4. Stork, V. T. (2003), "Large explanatory dictionary of the modern Ukrainian language", Irpin: VTF "Perun", Kyiv, Ukraine.

5. Zabarna, E. M. (2006), "Innovation and investment factor of economic development of Ukraine", Inst. of Market Problems and Economics experiment. NAS of Ukraine, Odessa, Ukraine.

6. Kokurin, D. I. (2001), "Innovative activity”, Moscow, Russia.

7. Lapin, E. V. (2002), "Economic potential of the enterprise: monograph", University Book. Sumy, Ukraine.
8. Lymych, Y. V. (2015), "Mechanisms of formation and use of innovation and investment potential of economic development", Odessa, Ukraine.

9. Lukinov, I. I. (1997), "Economic transformations (late twentieth century)", IE NAS of Ukraine, Kyiv, Ukraine.

10. Marchenko, E. M. and Razumova, M. V. (2007), "On the question of assessing innovation potential", VlGU, № 18, s. 16.

11. Meshko, N. P. (2008), "Investment and innovation potential of the region: evaluation criteria and problems of formation", Economic space, № 10, s. 78-88.

12. Mocherny, S. V., Nekrasov, V. N., Ovchinnikov, V. N. and Sekretaryuk, V. V. "Economic theory", available at: http://library.tuit.uz/skanir_knigi/book/ econ_teoriya/econ_teoriya.htm1

13. Namlieva, N. V. (2009), "Regulation of the management system of investment potential of enterprises". Materials of the International Internet Conference. "Current state and prospects for the development of financial law", Oct. 28, available at: http://ndi-fp.asta.edu.ua/conf/index.php?topic $=47.0$

14. Neubauer, H. (2002), "Innovative activities in small and medium enterprises", Problems of management theory and practice, № 3, s. 65-67.

15. Papp, N. V. (2009), "Peculiarities of formation of innovative potential of the region". Science in information space: materials V International scientificpractical conf., October 30-31, 2009: in 6 volumes. Dnipropetrovsk, Ukraine.

16. Priymachenko, D. V. (2005). "Institutional mechanism of formation and implementation of customs policy", Entrepreneurship, economy and law, № 11 , s. 17-20.

17. Sobolev, V. M. and Sherdyakov, V. E. (1996), "Investment and personnel management: features in transition economies", Business-Inform, Kharkiv, Ukraine.

18. Alchian, A. (1977), "Economic Forces at Work", Indianpolis.

Стаття надійшла до редакиії 11 червня 2021 р. 